\title{
Performance of hybrid cement composite elements under drop-weight impact load
}

\author{
V.D. Nguyen ${ }^{\mathrm{a}} \bowtie$, O. Río ${ }^{\mathrm{a}}$, V. Sánchez-Gálvez ${ }^{\mathrm{b}}$ \\ a. Instituto de Ciencias de la Construcción Eduardo Torroja IETcc_CSIC, (Madrid, Spain) \\ b. Universidad Politécnica de Madrid, (Madrid, Spain) \\ $\bowtie$ duc.nguyen@ietcc.csic.es
}

\begin{abstract}
The performance, under drop-weight impact load, of hybrid cement composite (HCC) elements, consisting of a top layer of plain concrete (PC) and a bottom layer of fibre reinforced concrete (FRC), in comparison with full-depth FRC and PC was studied. Apart from improving the tensile capacity of PC and saving fibre steel reinforcements of FRC, the results showed that HCC can effectively control the deformations and enhance the impact performance of the structural members as its outcomes were similar to that of a full-depth FRC. The analytical studies using Hughes empirical formulae (HEF) and yield line theory (YLT) adopted to investigate the practical use of HCC showed that they are applicable for design such HCC elements against impacts.
\end{abstract}

KEYWORDS: Hybrid cement composites; Fibre reinforcement; Drop-weight impact load; Impact theoretical analyses; Mayusculaocal and global dynamic response

Citation / Citar como: Nguyen, V.D.; Río, O.; Sánchez-Gálvez, V. (2014) Performance of hybrid cement composite elements under drop-weight impact load Mater. Construcc. 64 [314], e017 http://dx.doi.org/10.3989/mc.2014.06813.

RESUMEN: Comportamiento de elementos estructurales de compuestos híbridos base cemento frente a impacto de torre de caída. Se estudió el comportamiento, frente a impacto de torre de caída, de elementos híbridos base cemento (HCC), formados por una capa superior de hormigón en masa (PC) y una capa inferior de hormigón reforzado con fibras (FRC) en comparación con elementos análogos íntegramente fabricados con FRC y PC. Además de proporcionar una mejora en la resistencia frente a flexo-tracción de los PC y un ahorro en refuerzo usando fibras de acero en el caso de los FRC, los resultados mostraron que el HCC puede controlar eficazmente las deformaciones y mejorar el rendimiento frente a impacto de los elementos estructurales ya que sus resultados fueron análogos a la de los FRC. Los estudios analíticos, utilizando HEF e YLT, adoptados para investigar el uso práctico de los HCC mostraron que los mismos son aplicables para el diseño de estos elementos frente a impacto.

PALABRAS CLAVE: Compuesto hibrido base cemento; Fibra-reforzado; Carga de torre de caída; Análisis teórico de impacto; Respuesta dinámica local y global

Copyright: (C) 2014 CSIC. This is an open-access article distributed under the terms of the Creative Commons Attribution-Non Commercial (by-nc) Spain 3.0 License.

\section{INTRODUCTION}

Under impact situations, the material is required to absorb a large amount of energy within a short duration (1). Thanks to fibre inclusion, Fibre Reinforced Concrete (FRC) has much better properties under impact load than Plain Concrete (PC) does, in terms of both toughness and energy absorption $(2,3)$ Many kinds of fibres such as steel fibres (4), polypropelene fibres (5), glass fibres (6) etc. have been reported to improve FRC impact resistance significantly. Moreover during the last few decades, the importance 
of impacts and impulsive loads, such as those occurring due to accidental conditions as the ones caused by wind, hurricane or storms which generate missiles (debris, rocks, trees, vehicles, airplanes etc.), is an increasing concern $(1,7)$. For material research, this type of impact can be simulated experimentally by drop-weight impact load test (1).

It is also generally assumed that the beneficial effect of fibres in concrete matrix is much more significant in tension than that in compression (2). Thus, for the certain full-depth fibre reinforced concrete (FRC) element, an essential fraction of fibres is not utilized to its full potential. Typical examples are the FRC elements designed against different impulsive loadings $(4,7)$ and also those subjected to significant static loads under flexural bending $(8,9)$. At service stage, without considering substantial cracking, on the mid-span nearly half of the cross-section of such elements (at the top) is under compression. In this sense, many of fibres at the top layer are not used efficiently. Hence, it is important to develop new types of structures which optimize the properties of such FRC materials.

An alternative approach, based on the concept of functionally graded concrete $(10,11)$, is to define PC and FRC layers to arrange a Hybrid Cement Composite (HCC), which considers properly the actual compression-tension element behaviour $(8,10$, 12, 13). By strategically replacement of FRC by PC, considerable fraction of fibres, which dominate the cost of FRC elements such as beams (8), tunnel segments (9), or rigid pavements (14) would be saved. Even when the solution needs definition of more than two layers in order to consider sign variations of bending moment due to the quite different behaviour at support and mid-span.

Nevertheless, casting in layers at fresh state did not always guarantee the good bond between layers even when HCC element is subjected to static load $(8,13,14,15)$. As it was stated independently of material combined (16), a good bond can only be achieved if there is a smooth transition of stresses from one layer to another forming what is named as a functionally graded material (FGM).

In spite of the significance of the concept for being applied in structures subjected to impact $(1,4,7,17)$, and of the different research performed in the area of FGM $(10,11)$, there is a lack of theoretical and experimental studies regarding the structural behaviour of such hybrid sections under dynamic loads. Because of the different tensile properties between layers in HCC elements, the interface debonding or delamination might occur due to the increasing of internal stress at interface, particularly it could occur when HCC element is subjected to dynamic loads.

The objective of this paper is to study performance of structural HCC element under drop-weight impact load compared to the monolithic counterparts of
PC and FRC. Maximum impact load, accumulated energy absorption capacity and mode of failure against multiple impacts are aspects for assessing the impact performance among them. The study also focuses on the dynamic responses (local and global) and interface of HCC elements in order to comprehend whether there is a delamination between layers.

\section{EXPERIMENTAL PROGRAM}

\subsection{Structural samples}

The structural elements were made by using a Portland cement CEMI 52.5 (OPC), densified silica fume (DSF) and limestone filler (LF) as finer components, siliceous sand and siliceous aggregate with maximum size $10 \mathrm{~mm}$ (CA). A high range water reducer admixture (HRWRA) was used to keep w/c under control considering that the self-compacting mixes were designed to have a flow spread of about $650 \mathrm{~mm}$ and a 28-day compressive strength of 80-85 $\mathrm{MPa}$ (18). Some of the specimens were reinforced by using approximately $1 \%$ by volume of $30 \mathrm{~mm}$ long hooked-end, randomly oriented steel fibres, as the designed flexural tensile strength should be greater than $10 \mathrm{MPa}$. The mixes and their components were designed and characterized according to EHE-08 (19) and the fibres content was in agreement with literature recommendations $(2,13,20)$ in such type of studies. Table 1 presents the proportions of both plain (PC) and fibre reinforced (FRC) mixes as well as the results of main characterization such as compressive strength $\left(f_{c}\right)$, elastic modulus $\left(E_{c}\right)$, splitting tensile strength $\left(\mathrm{f}_{\mathrm{ct} 1}\right)$, flexural tensile strength $\left(\mathrm{f}_{\mathrm{ct} 2}\right)$, residual tensile strength $\left(\mathrm{f}_{\mathrm{r} 1}, \mathrm{f}_{\mathrm{r} 2}, \mathrm{f}_{\mathrm{r} 4}\right)$.

The types of structural elements were all slabs of size $310 \mathrm{~mm} \times 310 \mathrm{~mm} \times 60 \mathrm{~mm}$. This size was adopted to fit the steel frame span used with the drop-weight tower. Regarding to the casting of HCC slabs, they were prepared in two steps by using the wet-on-wet method proposed for designing a layered functionally graded concrete $(11,12)$. First, the FRC mix was cast with the depth of 30 $\mathrm{mm}$ and after an elapsed time of approximately 15 minutes, the second layer of PC was stacked above the first one without using any adhesive material or interface treatment. Meanwhile, the monolithic counterparts of PC and FRC were cast, as usual, by filling the mould up to the total depth of $60 \mathrm{~mm}$. At the age of $24 \mathrm{~h}$, the slabs were removed from moulds and cured at standard conditions $\left(20^{\circ} \mathrm{C} \pm 2\right.$ and $95 \pm 5 \% \mathrm{RH}$ ) in a climatic chamber up to the age of $28 \mathrm{~d}$ and then kept at laboratory condition up to the impact load test performed at the age of 30 days. Before testing, the elements were measured and visually checked. The overall information of slabs used for experimental tests are those included in Table 2 . 
TABLE 1. Mix proportions and main characterizations

\begin{tabular}{|c|c|c|c|c|c|}
\hline & & & Unit & PC & FRC \\
\hline \multirow{8}{*}{ Mix proportion } & $\mathrm{OPC}$ & & \multirow{8}{*}{$\mathrm{kg} / \mathrm{m}^{3}$} & 500 & 500 \\
\hline & DSF & & & 45 & 45 \\
\hline & LF & & & 50 & 50 \\
\hline & Sand & & & 821 & 821 \\
\hline & $\mathrm{CA}$ & & & 670 & 670 \\
\hline & $\mathrm{SF}$ & & & - & 80 \\
\hline & HRWRA & & & 14 & 16 \\
\hline & $\mathrm{W} / \mathrm{C}$ & & & 0.35 & 0.35 \\
\hline \multirow{2}{*}{$\begin{array}{l}\text { Rheological } \\
\text { characterization }\end{array}$} & Flow spread & $d_{f}$ & $\mathrm{~mm}$ & 660 & 620 \\
\hline & Flow time & $\mathrm{T}_{50}$ & $\mathrm{~s}$ & 6 & 6.5 \\
\hline \multirow{7}{*}{$\begin{array}{l}\text { Mechanical } \\
\text { characterization } \\
\text { at } 28 \text { days }\end{array}$} & Compressive strength $^{(1)}$ & $f_{c}$ & $\mathrm{MPa}$ & 84.6 & 82.1 \\
\hline & Elastic modulus $^{(2)}$ & $\mathrm{E}_{\mathrm{c}}$ & $\mathrm{GPa}$ & 38.3 & 38.1 \\
\hline & Splitting tensile strength ${ }^{(1)}$ & $\mathrm{f}_{\mathrm{ct} 1}$ & $\mathrm{MPa}$ & 5.8 & 8.9 \\
\hline & Flexural tensile strength $^{(1)}$ & $\mathrm{f}_{\mathrm{ct} 2}$ & $\mathrm{MPa}$ & 7.8 & 11.2 \\
\hline & \multirow{3}{*}{ Residual flexural strength ${ }^{(1)}$} & $\mathrm{f}_{\mathrm{r} 1}$ & $\mathrm{MPa}$ & - & 9.7 \\
\hline & & $\mathrm{f}_{\mathrm{r} 2}$ & $\mathrm{MPa}$ & - & 6.4 \\
\hline & & $\mathrm{f}_{\mathrm{r} 4}$ & $\mathrm{MPa}$ & - & 2.2 \\
\hline
\end{tabular}

(1) Average of three sample results.

${ }^{(2)}$ Individual test result.

\subsection{Drop-weight impact load test set-up}

The instrumented drop-weight impact tower used was a Dynatup 8250 included in Figure 1. This machine allows performing tests of different predetermined heights up to the maximum of $1030 \mathrm{~mm}$ and weights of $2.21,4.98,11.72,22.34,33.14$ or $44.02 \mathrm{~kg}$. The weight had to be installed onto the cross-head which bolts with load cell and a cylindrical hard impactor of $51 \mathrm{~mm}$ length and $12.7 \mathrm{~mm}$ diameter (d). The impactor had a hemispherical shape impact end on bottom. Regarding the impactor, it was noteworthy to state that its stiffness is of about $220 \mathrm{GPa}$ which compared to that of specimens is significantly higher ( $>5$ times).

The cross-head has an indication flag, which is used together with the laser sensor to trigger the Instron data acquisition system, used for recording during test the load vs time curve once the impactor was in contact with the slab. The machine had also an electro-mechanical system and a computer connected to the acquisition system. The electromechanical system was operated manually, to move the weight-load cell-impactor system freely up and down along the two stainless steel circular guide rods. Next to guide rods, there were two shock absorbers, which play the role of stopping the cross-head to protect the impactor from collision with other components. Grease was applied to guide rods in order to reduce friction along the rods and to ensure a controlled and smooth fall. The weight together with load cell and the impactor was dropped freely below the earth's gravitational acceleration of $9.81 \mathrm{~m} / \mathrm{s}$. An overall view of the apparatus and also a detail view of the testing area are shown in Figure 1. Moreover, an available program in the computer that allows calculating the velocity and energy absorption at the same time that load vs. time is registered. Numerical data of the curves are also provided in order to allow their post-process.

TABLE 2. Slabs used for experimental test

\begin{tabular}{llll}
\hline Material & PC & HCC \\
\hline Number of slab cast & FRC \\
Schematic view \\
(units in mm)
\end{tabular}




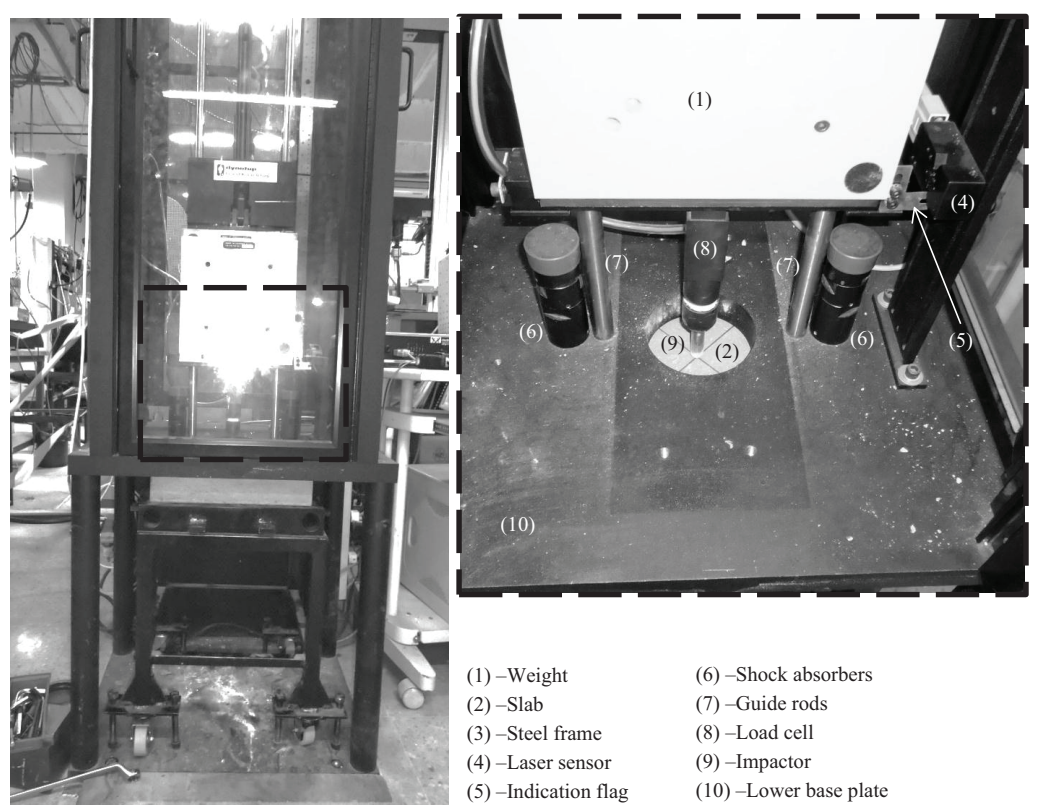

Figure 1. Drop-weight tower used in this study.

Lastly, the machine is complemented with a mobile rigid steel frame, as shown in Figure 2, which is used for simply placing the specimens to be tested without using any dissipating element. During each drop, the steel frame supports must be fixed by means of screws to laboratory floor of a dissipating material in order to absorb any vibration yielded from impact.

\subsection{Test procedure}

All of slabs were tested on a $354 \mathrm{~mm}$ diagonal span length with the impactor striking them at the mid-span of their top in as-cast direction, which was marked by the diagonal cross-lines, as it can be seen in Figure 2. For testing, the weight used was $33.14 \mathrm{~kg}$ or $44.02 \mathrm{~kg}$ (in two of the cases), and the drop height was kept constant in all of cases at $1030 \mathrm{~mm}$. Since the bearing guiding the impactor are almost frictionless, this gave an impact velocity of approximately $4 \mathrm{~m} / \mathrm{s}$ and strain rate was in the range of $10^{0}-10^{-2} \mathrm{~s}^{-1}$, which in turn is similar to those proposed by other authors for this type of experiment $(21,22)$. During each single drop weight, the impact load $(\mathrm{P})$ vs. time $(\mathrm{t})$ curve was the only data recorded. In present study, the response of the specimen itself, which is used for obtaining
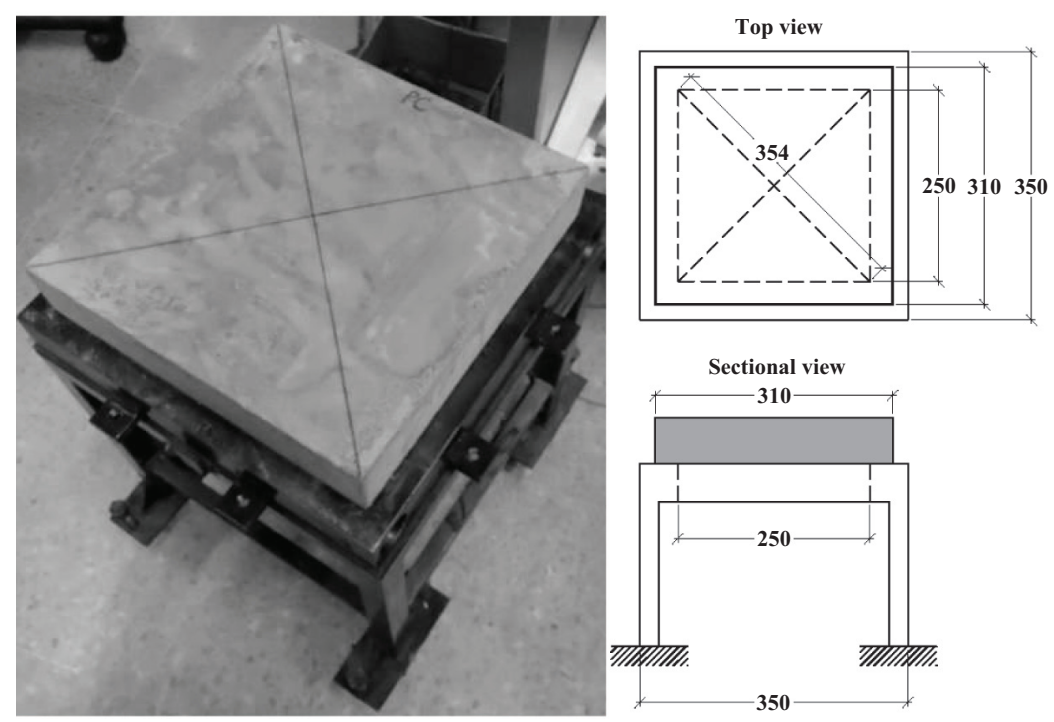

FIGURE 2. Slab support condition. 
the velocity $\left(v_{i}\right)$ and the absorbed energy $(\mathrm{E})$ at each impact, was not measured but calculated as it was also proposed in (23). All the slabs were subjected to a single or multiple impacts up to occurrence of failure which was considered to be when the hard impactor penetrated fully into the slab, as it can be seen in Figure 3.

It has been reported by some authors (24) that the experimentally observed load was not exactly the true bending load exerted on the slab and consequently suggested the use of an accelerometer attached to the specimen for measuring the response of the concrete element itself (25). However, a most recently study performed by using the same dropweight tower and test configuration described in sections 2.1 and $2.2(21)$, pointed out that the inertial load of the slabs can be considered negligible in such cases. Therefore, the impact velocity $\left(v_{i}\right)$ can be directly derived from the corresponding recorded impact load $\left(\mathrm{P}_{\mathrm{i}}\right)$. Using the load versus time history curves, the loss of kinetic energy could be also computed according to equation [1].

$$
E=\frac{1}{2} M\left(v_{i}^{2}-\left(v_{i}-\frac{1}{M} \int_{0}^{t} P d t\right)^{2}\right)
$$

where,

$\mathrm{E}=$ kinetic energy lost by the weight $(\mathrm{J})$

$\mathrm{M}=$ drop-weight impact $(\mathrm{kg})$

$v_{i}=$ impact velocity at the corresponding time $(\mathrm{m} / \mathrm{s})$

$\int_{0}^{t} P d t=$ the area below the load versus time curve $(\mathrm{kN} . \mathrm{s})$

As expressed in equation [1], the loss of kinetic energy from the impactor was obtained from weight, impact velocity and the area below the load versus time curve measured for each slab. It is wellknown that a major part of the energy loss from the impactor was absorbed by the slab kinetic energy, strain energy, and plastic work, whereas the rest was converted into noise and heat (1). In this study, as

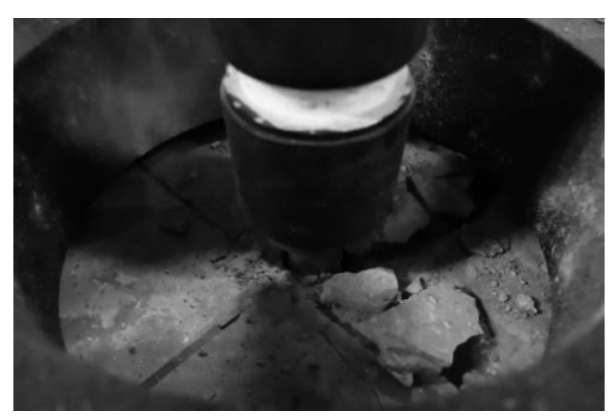

FIGURE 3. Finish of impact load test on a slab. all the other testing conditions were kept roughly the same, the energy loss from the impactor can be used as a measure of the energy absorption capacity of the material.

It must be noticed that prior to beginning each drop sequence the impactor was manually move down in order to check whether the laser sensor system was performed properly and its position was in coincidence with the centre of slab (cross-lines) or subsequently with that of previous impact. Afterward, the cross-head together with the weight, load cell and impactor was moved upwards for beginning test process and corresponding measurements.

\subsection{Preliminary tests}

As given above in Table 2, an extra slab of each type of material has been cast for performing preliminary tests, which consist of checking the possible numbers of drops needed to produce the slab failure with a given weight and the crack development. Considering this, during these preliminary tests the data were not registered though the properly machine performance was checked. As a result of these tests, it was decided to check how the FRC slabs perform under a higher weight of $44.02 \mathrm{~kg}$ ( 2 samples) but to keep the weight of $33.14 \mathrm{~kg}$ in the remaining cases.

\subsection{Record of damage}

When the structure receives an impact, other important consideration is to examine the local (such as indentation, spalling phenomenon, cone cracking, etc.) and global (crack formation, propagation, with, etc.) response or damage of structure (1). Some researchers have used a high speed camera to record damage during drop-weight tests (22), but this was not a case in this study. The degradation of slab in terms of crack propagation, crack development and crack width after each drop was recorded. This was done by mean of a special magnifying glass, as shown in Figure 4, which allowed measuring the crack width with accuracy of $0.01 \mathrm{~mm}$ or by mean of a crack ruler when the crack has been wide enough.

\section{ANALYSIS OF RESULTS AND DISCUSSION}

Table 3 shows both type of results those computed during test (such as velocity, maximum impact load, energy absorption capacity) and those measured after each impact like penetration depth. The Figure 5, 6 and 7 show the failure of PC slabs, degradation together with failure of HCC and FRC slabs respectively. The Figure 8 shows the load-time curves obtained for three type of material PC, HCC and FRC. 


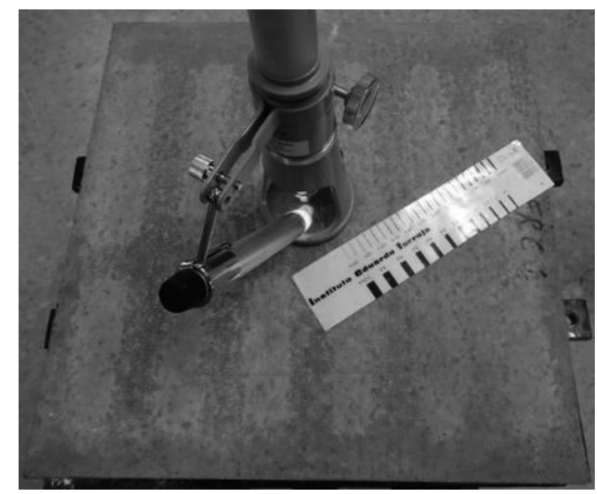

Figure 4. Crack width determined by mean of magnifying glass.

\subsection{Test results from each impact of determined weight}

As it was pointed out above, all of slabs were subjected to impact load in as-cast direction, hence, in case of HCC slabs, the impact or top face was that without fibre inclusion or PC layer and, consequently, the distal or bottom face was that with fibre inclusion or FRC layer. The weight level chosen to test first was $33.14 \mathrm{~kg}$. However, when testing of the first two FRC slabs with that weight, they truly showed better behaviour under multiple impacts compared to PC and HCC tested previously. For instance, the FRC slab, which was used for preliminary test, failed only after four impacts. Therefore, it was attempted to study the limitation of this material, and the weight was raised up to $44.02 \mathrm{~kg}$ for testing the last two FRC slabs (S8, S9).

The PC slabs were broken immediately after a single impact of the weight $33.14 \mathrm{~kg}$, as it can be seen in Table 3. The matrix seemed to be rather brittle. As an impactor hit, the slabs failed instantaneously and the penetration depth was in the range of $2-3 \mathrm{~mm}$. Meanwhile, the HCC slabs failed after double impacts and the FRC slab S7 failed after triple impacts under the same drop weight of $33.14 \mathrm{~kg}$. The penetration depth of HCC slabs after the first impact was in the range of $11-13 \mathrm{~mm}$, while that of the slab S7 was about 7-8 $\mathrm{mm}$. This was due to the spalling of the PC around the spot in contact with an impactor on the impact face of HCC slabs, while that spot was slightly indented on the impact face of slab S7. Since steel fibre inclusion on impact face of FRC slab increased toughness and shear strength (4), which resulted in diminishing the penetration depth compared to that of HCC slabs.

In case of the other FRC slabs S8 and S9, since the impact weight was increased up to $44.02 \mathrm{~kg}$, the impactor penetrated fully into the slabs after double impacts. The penetration depth of these slabs was moderately higher than that of slab S7 after the first impact, as shown in Table 3. Under the first impact of weight $44.02 \mathrm{~kg}$, impact load resistance of slabs S8 and S9 were nearly as same as that of slab S7, nonetheless, the energy absorption capacity has increased notably. It indicated that after a single impact of weight $44.02 \mathrm{~kg}$ the slabs S8 and S9 had more internal damage than the slab S7 did, when it was subjected to impact of weight $33.14 \mathrm{~kg}$. The fibre pull-out was observed predominantly at the fractured zones of HCC and FRC slabs.

\subsection{Cracking behaviour}

The failure of the PC slabs under impact was catastrophic, as it can be seen in Figure 5. The cracks formed in the PC slabs were mostly close to the diagonal sections of slabs and the slab shattered into four or five sizable pieces. The failure of the PC slabs may be foreseen as follows: On striking the slab, the impactor penetrated the slab and during

TABLE 3. Velocity of impactor, maximum impact loads, penetration depth and energy absorption capacity obtained from each experimental test

\begin{tabular}{|c|c|c|c|c|c|c|c|c|c|c|c|c|c|c|c|}
\hline \multirow[b]{2}{*}{ Material } & \multirow[b]{2}{*}{ ID } & \multicolumn{2}{|c|}{$\begin{array}{c}\text { Impact up to } \\
\text { failure } \\
\end{array}$} & \multicolumn{3}{|c|}{$\begin{array}{c}\text { Velocity of } \\
\text { impactor }(\mathrm{m} / \mathrm{s})\end{array}$} & \multicolumn{3}{|c|}{$\begin{array}{l}\text { Maximum load after } \\
\text { each impact }(k N)\end{array}$} & \multicolumn{3}{|c|}{$\begin{array}{l}\text { Maximum penetration } \\
\text { depth after each } \\
\text { impact }(\mathrm{mm})\end{array}$} & \multicolumn{3}{|c|}{$\begin{array}{c}\text { Energy absorption } \\
\text { capacity after each } \\
\text { impact }(J)\end{array}$} \\
\hline & & No. & $\begin{array}{l}\text { Weight } \\
\text { (kg) }\end{array}$ & $\underset{\text { I }}{\text { Impact }}$ & $\underset{\text { II }}{\text { Impact }}$ & $\begin{array}{c}\text { Impact } \\
\text { III }\end{array}$ & $\underset{\text { I }}{\text { Impact }}$ & $\underset{\text { II }}{\text { Impact }}$ & $\underset{\text { III }}{\text { Impact }}$ & $\underset{\text { Impact }}{\text { Im }}$ & $\begin{array}{c}\text { Impact } \\
\text { II }\end{array}$ & $\underset{\text { III }}{\text { Impact }}$ & $\underset{I}{\text { Impact }}$ & $\begin{array}{c}\text { Impact } \\
\text { II }\end{array}$ & $\begin{array}{c}\text { Impact } \\
\text { III }\end{array}$ \\
\hline \multirow{4}{*}{ PC } & $\mathrm{S} 1$ & 1 & 33.14 & 4.24 & - & - & 34.37 & - & - & 2.45 & - & - & 249.72 & - & - \\
\hline & $\mathrm{S} 2$ & 1 & 33.14 & 4.19 & - & - & 62.42 & - & - & 2.98 & - & - & 163.06 & - & - \\
\hline & S3 & 1 & 33.14 & 4.18 & - & - & 47.64 & - & - & 2.03 & - & - & 257.68 & - & - \\
\hline & $\mathrm{S} 4$ & 2 & 33.14 & 4.23 & 4.22 & - & 52.38 & 58.50 & - & 12.31 & 35.99 & - & 301.04 & 282.60 & - \\
\hline \multirow[t]{3}{*}{$\mathrm{HCC}$} & S5 & 2 & 33.14 & 4.20 & 4.25 & - & 59.73 & 25.86 & - & 11.09 & 39.43 & - & 295.56 & 250.85 & - \\
\hline & S6 & 2 & 33.14 & 4.23 & 4.25 & - & 50.44 & 52.65 & - & 11.31 & 32.14 & - & 299.53 & 292.41 & \\
\hline & S7 & 3 & 33.14 & 4.24 & 4.24 & 4.23 & 63.66 & 72.56 & 58.11 & 7.43 & 5.90 & 16.49 & 300.40 & 300.26 & 230.34 \\
\hline \multirow[t]{2}{*}{ FRC } & $\mathrm{S} 8$ & 2 & 44.02 & 4.21 & 4.23 & - & 60.52 & 64.56 & - & 12.56 & 19.59 & - & 395.71 & 397.67 & - \\
\hline & S9 & 2 & 44.02 & 4.21 & 4.21 & - & 70.23 & 40.410 & - & 8.06 & 24.53 & - & 394.61 & 401.45 & - \\
\hline
\end{tabular}


the contact period, very high stresses developed in the vicinity of impact spot and formed cone-shaped stress distributed towards distal face. The slab losing integrity and gaining momentum experienced large displacements inducing radial cracks formation.

On the contrary, under the first impact of weight $33.14 \mathrm{~kg}$, the crack was not formed on the impact face of the HCC slabs, except the spalling of PC at the area of impact point; on the distal face, several cracks originating from centre to the edges of slab were observed and the maximum width was of 0.1 $\mathrm{mm}$, as crack map is shown in Figure 6a. After the second impact, the impactor penetrated fully into the slab and pushed a frustum cone-shaped plug off, as illustrated in Figure 6b. The fibres held the plug to hinder its separation from slab. Although an impactor penetrated into the HCC slabs after double impacts of weight $33.14 \mathrm{~kg}$, they have still maintained the integrity, while the PC slabs have already broken into pieces after a single impact of weight $33.14 \mathrm{~kg}$. It was due to the steel fibre presence helped in holding the fractured parts together.

Under the same drop-weight impact of $33.14 \mathrm{~kg}$ the impact face of FRC slab S7was slightly indented by spherical-ended body of an impactor and suffered less damage than HCC and PC slabs did after the first impact. Several cracks were propagated on the distal face with the maximum width of $0.08 \mathrm{~mm}$, as crack map is seen in Figure 7a. The second impact has caused crack propagation on the impact face with the maximum width of $0.6 \mathrm{~mm}$ and slightly spalling; however, the crack opening has increased on the distal face with the maximum width of $2.5 \mathrm{~mm}$, as illustrated in Figure 7b. The penetration of impactor occurred on the impact face after the third impact and the cracks have developed broadly on the distal face up to maximum width of $10 \mathrm{~mm}$, as it can be seen in Figure 7c.

The spalling phenomenon is explained in the literature that due to the reflection of elastic wave from distal face to impact face causing the tensile strain higher than failure tensile strain of material (PC or FRC) and, consequently, led to chipping or splintering of material in the vicinity of impact point (24). It was noteworthy that HCC and FRC slabs with fibre inclusion partially and fully respectively showed significantly superior impact performance compared to PC slabs. Fibres in those slabs have played an important role as a crack arrestor to restrain against the development and propagation of cracks through

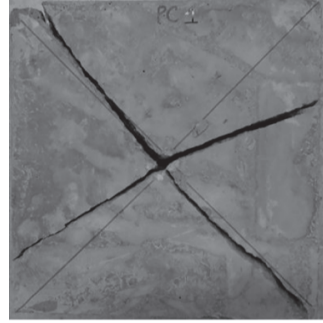

a)

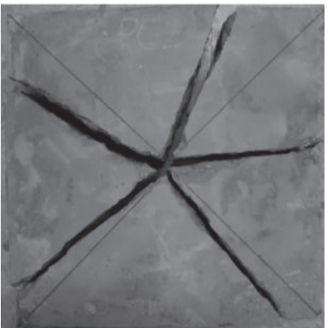

b)

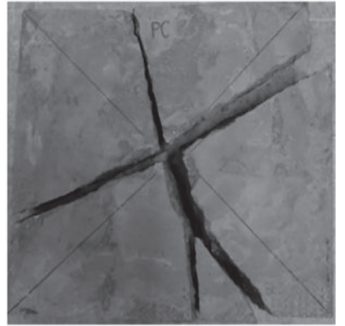

c)

Figure 5. Impact faces of PC slabs after impact load test a) S1; b) S2 and c) S3.

a)

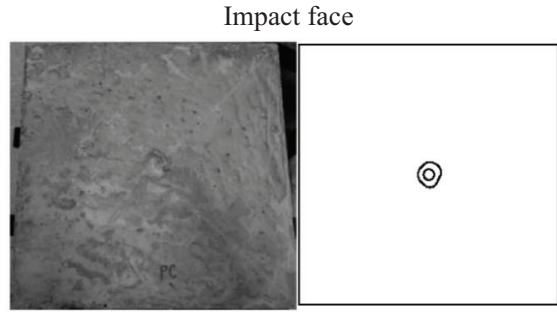

b)

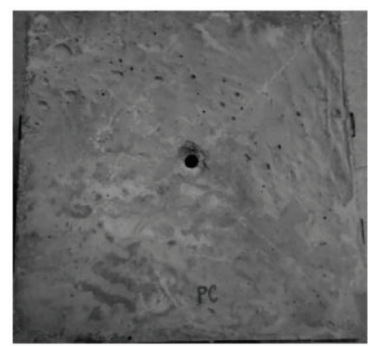

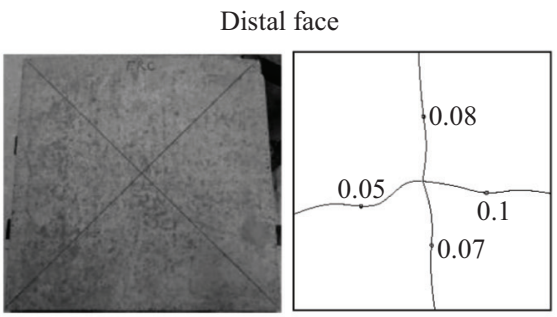

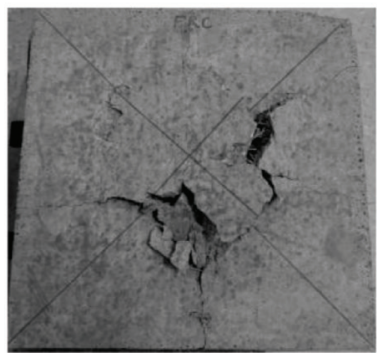

FIGURE 6. Crack formation in the impact and distal faces of HCC slab S6 after a) impact I (Units of crack width in mm); b) impact II. 

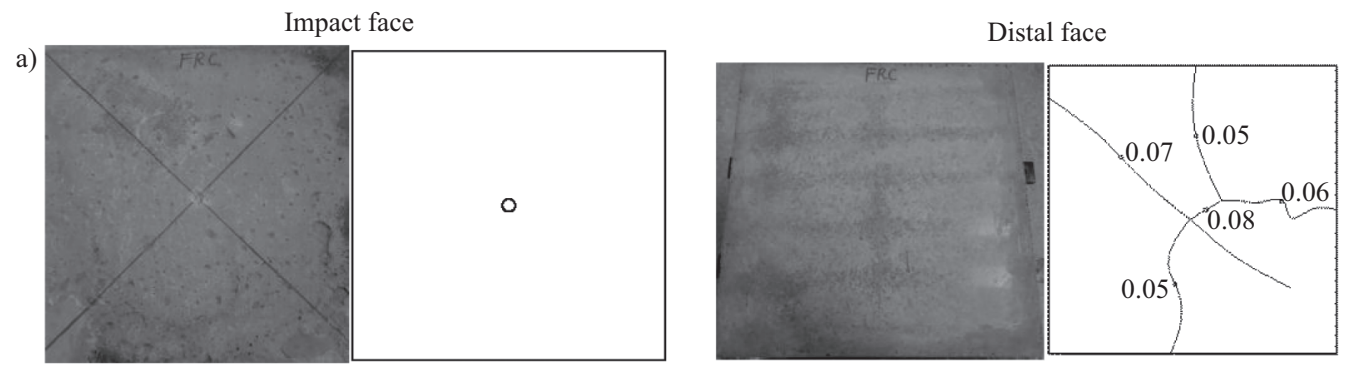

b)
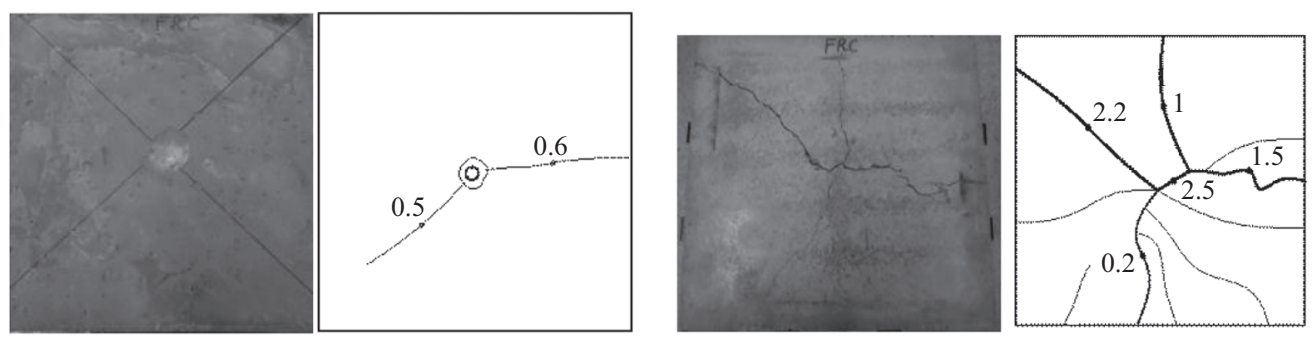

c)
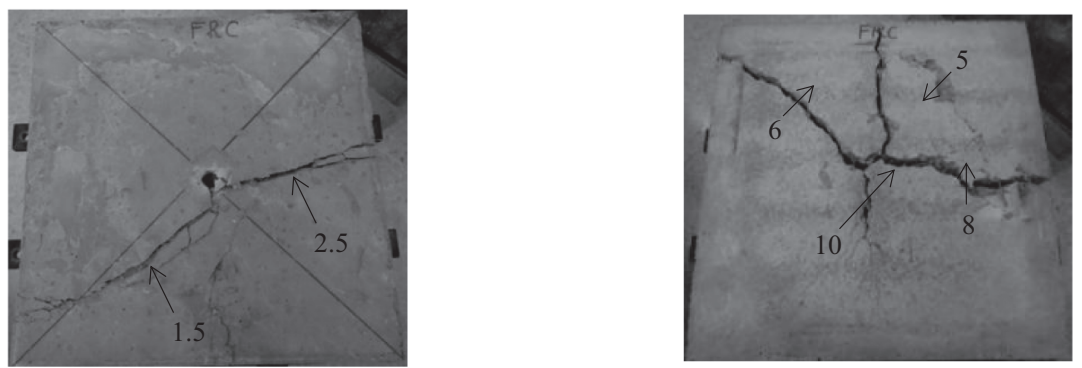

FIGURE 7. Crack formation on the impact and distal faces of FRC slab S7 after a) impact I; b) impact II; c) impact III (Units of crack width in $\mathrm{mm}$ ).

fibre bridging action. The stress was transferred from matrix to fibres which, in turn, make the material become tougher under impact load.

\subsection{Load versus time history characteristic of PC, HCC and FRC slabs tested}

Figure 8 shows the load versus time history curve of slabs S3, S5 and S7 representing the material PC, HCC and FRC respectively after the single impact of weight $33.14 \mathrm{~kg}$. In general, the slab experienced a rapid increase in the load giving rise to the maximum load. This sudden increase in load to the maximum value occurred within $0.5 \mathrm{~ms}(0.5$ millisecond $)$ for the slabs tested. The multiple contacts between the slab and the impactor were characterised by the occurrence of multiple peaks, referred as "secondary peak". According to several authors (25), the peak loads may be influenced by various parameters such as velocity of impactor, mass of the weight, noseshape of impactor, slab thickness, etc. However, in this study the above parameters were maintained constantly among the slabs and hence for the slabs tested, the peak load was assessed mainly by the type of material.
According to the load versus time history curves, it was seen that the slab S3 did not show the secondary peak. After reaching the maximum load, the curve fell down steeply and the impact experienced

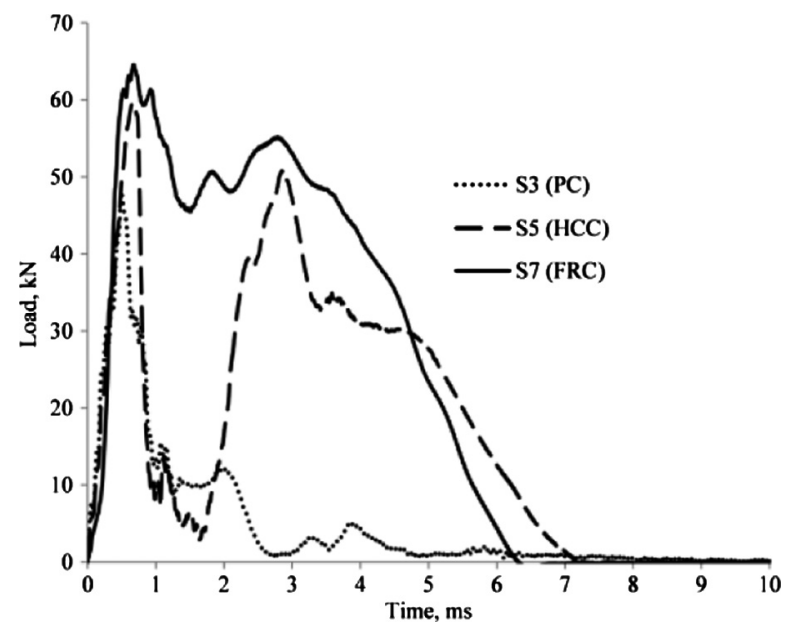

Figure 8. Load versus time history curve of PC slab S3, HCC slab S5 and FRC slab S7 after the single impact of weight $33.14 \mathrm{~kg}$. 
only during about $2 \mathrm{~ms}$. This indicated why the penetration depth was only $2 \div 3 \mathrm{~mm}$, as given in Table 3. On the contrary, the slabs S5 and S7 showed the secondary peak during the single impact of weight $33.14 \mathrm{~kg}$. After the primary peak, the spalling of PC on the impact face of slab S5 has caused the reduction of load up to $10 \mathrm{kN}$ at about $2 \mathrm{~ms}$, meanwhile, the reduction of load in case of slab S7 only up to about $45 \mathrm{kN}$. It might be due to the absence of spalling on FRC slabs during the single impact. After diminishing of load, the slabs S5 and S7 have resisted higher load and the secondary peak was observed before the impact experience was finished at about $7 \mathrm{~ms}$. Although, the two peak loads of S5 slab were lower than those of S7 slab, the performance tendency of both HCC and FRC material were quite similar under impact load.

\subsection{Comparative ratio of $\mathrm{HCC}$ with $\mathrm{PC}$ and $\mathrm{FRC}$ slabs in terms of impact load and energy absorption capacity}

Since all of tested slabs have damaged after a single impact such as failure of PC slabs or crack propagation in HCC and FRC slabs, the data in terms of maximum impact load from impact I of Table 3 was taken into account for comparative study together with accumulated energy absorption, which is the sum of energy absorption capacity from each impact. Table 4 shows an average maximum impact load (a single impact) and accumulated energy absorption for each type of material.

As given in Table 3, the maximum impact load and energy absorption capacity of PC slabs were varied in the range of $34-63 \mathrm{kN}$ and $163-257 \mathrm{~J}$. As a result of that, the standard deviation of PC slabs were markedly large, as shown in Table 4, it means that the coefficient of variation $(\mathrm{COV})$ of this material is quite high. This phenomenon has been also reported previously in (26), where the COV of PC elements was even up to $51 \%$ under drop-weight impact test. Yet, the impact resistance results of PC barely had a normal distribution under the statistical and experimental analysis (27). However, the maximum impact load after a single impact and accumulated energy absorption of FRC and HCC slabs were quite close one to another. Thus, the standard deviation of those slabs was smaller than that of PC slabs, as shown in Table 4.
While PC and FRC slabs were built monolithically, the HCC slabs were built in two layers of FRC and PC mixes, the maximum impact load of HCC slabs was approximately $13-74 \%$ greater than that of PC slabs and about $18-39 \%$ smaller than that of FRC slabs. Yet, the HCC slabs absorbed 2.6 times more energy than PC slabs did and only $41 \%$ less than FRC slabs did.

Although there was a scatter of obtained data, the test results emphasized an enhanced impact performance of HCC slabs under impact load compared to that of PC slabs. Undoubtedly, FRC slabs showed better behaviour than HCC slabs did, in terms of ductility and toughness under impact load, but it had to take into account that the volume fraction of fibre used in HCC slabs was only a half of that in FRC slabs.

\subsection{Analysis of HCC slabs}

\subsubsection{Local dynamic response}

In general, the global structural response and failure of the PC, HCC and FRC slabs were quite similar and characterised by the formation of flexural cracks emanating from the centre towards the corners and edges of the slab, as same as reported in other studies on concrete slabs subjected to dropweight impact test $(28,29,30,31)$. However, the local response of HCC slabs was somehow different from the other slabs. At failure stage, the striking of impactor has produced a frustum cone-shaped plug on HCC slabs, as it can be seen in Figure 9a. The top diameter of frustum cone-shaped plug equals to impactor diameter. Looking into Figures 6a and $9 \mathrm{a}$, the first impact has caused the radial cracks on distal face of HCC slabs. The reflection of elastic wave caused spalling on impact face; it implied that the radial and curved shear cracks have developed and the frustum cone-shaped plug was formed on PC layer. During the second impact, the impactor has pushed the plug, sheared it off the surrounding composite and continued penetrating through the slabs. The curved shear cracks have somehow continued developing toward distal face. It pointed out that there was the transient behaviour from PC layer to FRC layer under impact load and HCC slabs, tested in this study, showed local response of punching shear or cone cracking.

TABLE 4. Average maximum impact load after a single impact and accumulated energy absorption for each type of slab

\begin{tabular}{lcccccc}
\hline & \multicolumn{2}{c}{ Maximum impact load from Impact I (kN) } & & \multicolumn{3}{c}{ Accumulated energy absorption (J) } \\
\cline { 2 - 3 } \cline { 5 - 6 } Materials & Average & Deviation & Ratio with HCC & Average & Deviation & Ratio with HCC \\
\hline PC & 48.14 & 11.50 & 0.88 & 223.49 & 42.85 & 0.39 \\
HCC & 54.18 & 4.00 & 1 & 574.00 & 17.14 & 1 \\
FRC & 63.85 & 4.50 & 1.17 & 806.81 & 19.80 & 1.41 \\
\hline
\end{tabular}



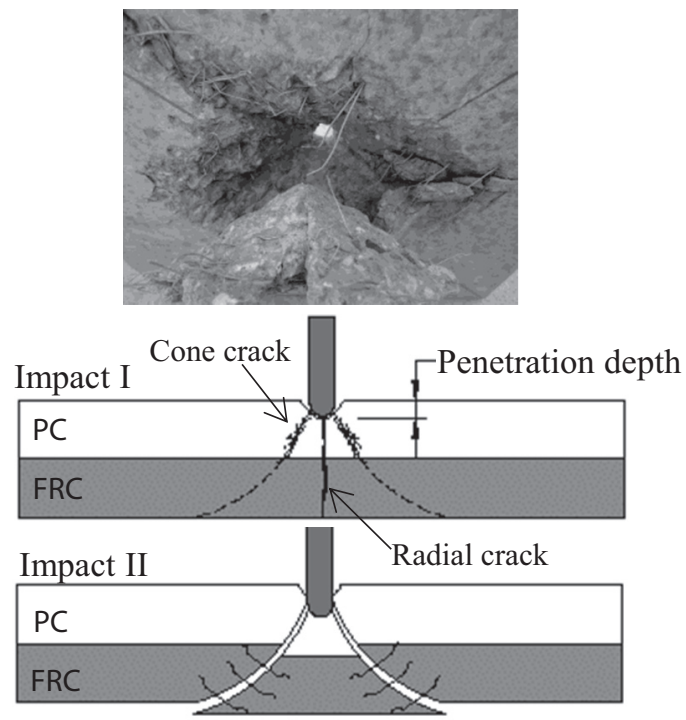

a)

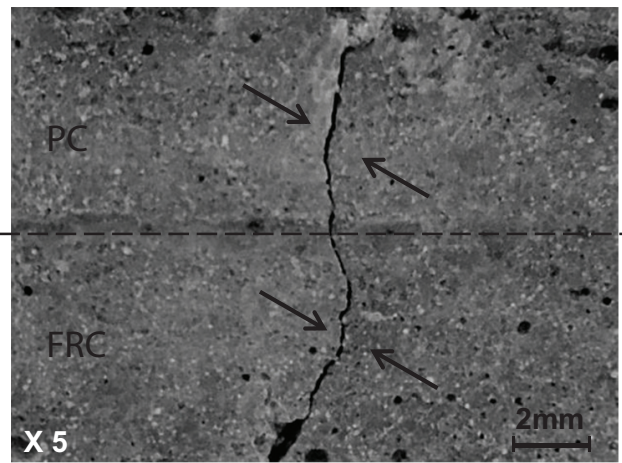

b)

FIGURE 9. Distal face of HCC slab S6 at post-test: a) bell-shaped failure; b) typical crack formed across the layers of HCC slabs on lateral side after impact load.

During the contact period with impactor, the PC slabs lost their integrity swiftly, hence, the local response of the slabs was not observed. Looking at Figure $7 \mathrm{c}$, the impactor penetrated into FRC slab on impact face and the crack width at centre was $10 \mathrm{~mm}$ on distal face, which is slightly smaller than impactor diameter $(12.7 \mathrm{~mm})$. Taking into account measuring was carried out at residual stage; it indicated that the impactor would have perforated the FRC slab if the length of impactor has been greater than the thickness of slab.

\subsubsection{Global dynamic response}

The global damage of HCC slabs was observed that the radial cracks have also developed across the layers on lateral sides, as seen in Figure 9b, and there was no trace of adhesive failure or debonding interface between layers. Theoretically, under dynamic load not only longitudinal wave causing radial and shear stresses is created, but also transverse wave travels toward rear surface (32). In this case, longitudinal wave causing the transient behaviour seemed to be dominated in HCC slabs, which, in turn, the transverse wave was aggravated. If the transient or transfer stress was deterred or stopped at interface due to the huge dissimilarity of materials, since the total energy is constant (33), longitudinal wave would somewhat be converted into transverse wave. In such case, the transverse wave would travel along the interface, cause shear stress and lead to delamination as the worst effect (34). The dissimilarity of materials in HCC slabs of this study was merely steel fibres included in one of layers. Since the delamination between layers did not occur, the type of fibre and its volume fraction used in HCC slabs was quite relevant.

\subsection{Empirical analysis of PC, FRC and HCC materials under impact load}

Owing to complexities in evaluating structural damage such as penetration, perforation, spalling and scabbing due to impact load, design criteria so far developed have been mainly dependent on experimental tests and empirical formulae (35). There are about twenty empirical formulae that used to be employed in connection with missile impact problem on a massive concrete structure such as Petry, BRL, ACE, NDRC, Kar, Hughes formula, etc., which have been described extensively in the literature $(35,36)$. However, most of them employed compressive strength of concrete together with missile data in their formulae, which consequently do not give good or realistic results in comparison, especially in this study compressive strength of PC and FRC are quite similar, the main difference between them is tensile strength. The unique formula among twenty of them dealing with tensile strength of concrete is Hughes formula (36). This formula enables one to calculate the empirical penetration depth for given missile data and also gives the thickness that would be required to prevent perforation and scabbing. The empirical formulae are expressed in equations $[2,3,4]$ :

$$
x_{e m}=0.19 * d * \frac{N_{h} * I_{h}}{S}
$$


where,

$\mathrm{x}_{\mathrm{em}}=$ empirical penetration depth ( $\left.\mathrm{mm}\right)$

$\mathrm{N}_{\mathrm{h}}=$ impactor nose-shape factor $\left(\mathrm{N}_{\mathrm{h}}=1.26\right.$ for spherical-ended bodies in this study)

$$
\mathrm{I}_{\mathrm{h}}=\text { non-dimensional impact factor and } I_{h}=\frac{M * V_{0}^{2}}{d^{3} * f_{t}}
$$

$\mathrm{S}=$ strain-rate factor and $S=1.0+12.31 \mathrm{n}\left(1+0.03 * I_{h}\right)$

$\mathrm{M}=$ drop-weight impact $(\mathrm{kg})$

$\mathrm{V}_{\mathrm{o}}=$ impactor velocity $(\mathrm{m} / \mathrm{s})$

$\mathrm{d}=$ impactor diameter $(\mathrm{mm})$

$\mathrm{f}_{\mathrm{t}}=$ tensile strength $(\mathrm{MPa})$

$$
\begin{array}{ll}
x_{p}=\beta\left(1.58 * x_{e m}+1.4 * d\right) & \text { for } \quad \frac{x_{e m}}{d} \geq 0.7 \\
x_{s c}=\beta\left(1.74 * x_{e m}+2.3 * d\right) & \text { for } \quad \frac{x_{e m}}{d} \geq 0.7
\end{array}
$$

where,

$\mathrm{x}_{\mathrm{p}}=$ required thickness of target to prevent perforation (mm)

$\mathrm{x}_{\mathrm{sc}}=$ required thickness of target to prevent scabbing $(\mathrm{mm})$

$\beta=$ safety factor in the range of $1.2-1.3$ and equals to 1.3 adopted for this study

Using the tensile strength of PC, FRC and HCC, which have been reported previously elsewhere in (12), impactor properties, the corresponding impact weight and velocity of impactor from Impact I given in Table 3 as missile data, the penetration depth was calculated by solving equations [2] and then it was substituted to equations [3] and [4] for computing required thickness of PC, FRC and HCC target to prevent perforation and scabbing respectively. The empirical results are showed in Table 5. They are then compared to experimental results from a single impact or Impact I of each material PC, FRC and HCC because as mentioned above after a single impact all of tested slabs have damaged.

In order to protect concrete structure under impact load properly, the real thickness of slabs needs to be greater than required thickness to prevent both perforation $\left(\mathrm{x}_{\mathrm{p}}\right)$ and scabbing $\left(\mathrm{x}_{\mathrm{sc}}\right)$. Looking into the empirical results in Table 5, real thicknesses of PC slabs are smaller than the required thickness to prevent scabbing; consequently slabs were not able to be prevented from scabbing under drop-weight impact of $33.14 \mathrm{~kg}$. That is somehow a reason why those slabs failed instantaneously under a single impact.

Not like the case of material PC, under the same drop-weight impact of $33.14 \mathrm{~kg}$ the required thickness of slab to prevent perforation $\left(\mathrm{x}_{\mathrm{p}}\right)$ and scabbing $\left(\mathrm{x}_{\mathrm{sc}}\right)$ are smaller than real thicknesses of HCC slabs and FRC slab S7. It is mainly due to tensile strength of material FRC and HCC are higher than that of material PC. It depicts that HCC slabs and the FRC slab S7 can sustain the impact load of drop-weight $33.14 \mathrm{~kg}$, indeed, after a single impact, those slabs have merely damaged very slightly, the crack width in distal face was equal or smaller than $0.1 \mathrm{~mm}$, as it can be seen in Figure 6 and 7. Furthermore, it is seen in Table 5 that the empirical $\left(\mathrm{x}_{\mathrm{em}}\right)$ and experimental $\left(\mathrm{x}_{\mathrm{ex}}\right)$ penetration depth of those slabs are quite similar even though the $\mathrm{x}_{\mathrm{em}}$ in Hughes formula was derived from testing a massive concrete structure with a semi-infinite thickness (36).

In case of FRC slabs $\mathrm{S} 8$ and $\mathrm{S} 9$ the required thickness of slab to prevent and scabbing $\left(\mathrm{x}_{\mathrm{sc}}\right)$ was higher than the real thickness of slabs and the $x_{e m}$ and $\mathrm{x}_{\mathrm{ex}}$ of those slabs are also quite similar; consequently, those slabs are not able theoretically to withstand under impact load of drop-weight $44.02 \mathrm{~kg}$. However, it needs to bear in mind that the empirical formulae only employ tensile strength of FRC and does not take into account the post-

\begin{tabular}{|c|c|c|c|c|c|c|}
\hline \multirow[b]{3}{*}{ Material } & \multirow[b]{3}{*}{ ID } & $\begin{array}{c}\text { Real thickness of } \\
\text { tested slabs }\end{array}$ & $\begin{array}{c}\text { Experimental } \\
\text { penetration depth } x_{\mathrm{ex}}\end{array}$ & $\begin{array}{c}\text { Empirical penetration } \\
\text { depth } x_{\mathrm{em}}\end{array}$ & $\begin{array}{l}\text { Empirical required } \\
\text { thickness of target to } \\
\text { prevent perforation } x_{p}\end{array}$ & $\begin{array}{l}\text { Empirical required } \\
\text { thickness of target to } \\
\text { prevent scabbing } x_{\mathrm{sc}}\end{array}$ \\
\hline & & \multicolumn{5}{|c|}{ Impact I } \\
\hline & & \multicolumn{5}{|c|}{$\mathrm{mm}$} \\
\hline \multirow{4}{*}{$\mathrm{PC}$} & $\mathrm{S} 1$ & 60.49 & 2.45 & 11.08 & 45.87 & 63.03 \\
\hline & $\mathrm{S} 2$ & 60.55 & 2.98 & 10.98 & 45.67 & 62.81 \\
\hline & $\mathrm{S} 3$ & 60.32 & 2.03 & 10.96 & 45.63 & 62.77 \\
\hline & $\mathrm{S} 4$ & 60.92 & 12.31 & 10.03 & 43.71 & 60.36 \\
\hline \multirow[t]{3}{*}{$\mathrm{HCC}$} & S5 & 60.75 & 11.09 & 9.98 & 43.61 & 60.25 \\
\hline & S6 & 60.97 & 11.31 & 10.03 & 43.71 & 60.36 \\
\hline & S7 & 60.84 & 7.43 & 9.74 & 43.11 & 60.00 \\
\hline \multirow[t]{2}{*}{ FRC } & S8 & 60.56 & 12.56 & 10.68 & 45.05 & 62.13 \\
\hline & S9 & 60.94 & 8.06 & 10.68 & 45.05 & 62.13 \\
\hline
\end{tabular}
cracking behaviour or toughness of FRC, which

TABLE 5. Empirical results of material PC, HCC and FRC by Hughes formula 
is an essential property of FRC as well. This is a deficiency of empirical formulae which needs to be enhanced.

It is noted that the $\mathrm{x}_{\mathrm{em}}$ and $\mathrm{x}_{\mathrm{ex}}$ of PC slabs have a big discrepancy about $11 \mathrm{~mm}$ and $2.5 \mathrm{~mm}$ respectively, as shown in Table 5. It is due to the empirical formulae are used for a massive concrete structure with a semi-infinite thickness, in this study when the impactor penetrated $2.5 \mathrm{~mm}$, the slab failed immediately and the penetration of impactor stopped. If PC slabs have had higher thickness, the $\mathrm{x}_{\mathrm{em}}$ and $\mathrm{x}_{\mathrm{ex}}$ of those slabs would have had a minor discrepancy. On one hand, since the Hughes formula employs the tensile strength of material, the empirical analysis of PC, FRC and HCC somehow manifests the experimental results in this study. On the other hand, the empirical formulae still do not take into full consideration of fibre role in structure.

\subsection{Analysis of slabs based on an extended yield line theory}

In order to assess the static ultimate load of slabs, analysis of slab in failure regime can be done based on an extended yield line theory (37). When any slab is subjected under bending moment $\mathrm{Mp}$ yielded from concentrated load $\mathrm{P}$ at slab's centre, based on conservation of virtual work which prescribes the internal virtual work equals to the external virtual work, the ultimate static load can be derived as eight times of bending moment, which is given in equation [5].

$$
P_{s}=8 * M_{p}
$$

Where:

$\mathrm{P}_{\mathrm{s}}=$ static load $(\mathrm{kN})$;

$\mathrm{Mp}=$ elastic moment (kN.m) and $M_{p}=\frac{f_{t} * I}{y}$

$\mathrm{f}_{\mathrm{t}}=$ tensile strength $(\mathrm{MPa})$

$\mathrm{y}=$ depth of slab under tensile stress (m)

$\mathrm{I}=$ second inertia moment per unity $\left(\mathrm{m}^{4}\right)$
The ultimate static load of each slab has been calculated and included in Table 6 and the ultimate dynamic load of each slab is considered as a maximum load yielded from all impacts given in Table 3 . It is seen that the dynamic load from experimental tests has higher deviation than the static load from theoretical analysis. Furthermore, the correlation of dynamic and static load is within the same order of magnitude that prescribed in design code for concrete structures against impact (38).

Despite of the limited number of data, three slabs for each material, the significant outcomes of HCC have been revealed in this study. The maximum impact load and accumulated energy absorption capacity of HCC slabs were not too much lower than that of FRC slabs and considerably higher than that of PC slabs. HCC slabs entailed only a half of fibre volume fraction used for FRC slabs. That implied an advantage in terms of material saving or cost reduction. The adhesive failure or delamination did not occur; an interface of HCC slabs could be relied on being intact under impact load. Those are important highlights proving the viability of HCC. In view of further research, it would be desirable to conduct more slabs including full-scale HCC slabs with different thickness of PC and FRC layers under impact load test (this would of course require much larger funding).

\section{CONCLUSIONS}

The experimental and analytical results from drop-weight impact load tests on PC, FRC and HCC slabs showed the following conclusions:

1. The maximum impact load of HCC slabs was about $13-74 \%$ higher than that of PC and $18-39 \%$ lower than that of FRC slabs. However, compared to the PC slabs failed swiftly after a single impact, the HCC slabs behaved quasi-ductile and only failed after double impacts of the same drop weight used for testing PC slabs. This occurred

TABLE 6. Correlation between dynamic and static loads

\begin{tabular}{|c|c|c|c|c|c|c|c|}
\hline \multirow[b]{2}{*}{ Material } & \multirow[b]{2}{*}{ ID } & \multicolumn{3}{|c|}{ Ultimate dynamic load (kN) } & \multicolumn{3}{|c|}{ Ultimate static load (kN) } \\
\hline & & Each value & Mean value & Deviation & Each value & Mean value & Deviation \\
\hline & $\mathrm{S} 1$ & 34.37 & & & 37.37 & & \\
\hline \multirow[t]{3}{*}{$\mathrm{PC}$} & $\mathrm{S} 2$ & 62.42 & 48.14 & 11.5 & 38.07 & 37.71 & 0.29 \\
\hline & $\mathrm{S} 3$ & 47.64 & & & 37.68 & & \\
\hline & S4 & 58.50 & & & 48.42 & & \\
\hline \multirow[t]{3}{*}{$\mathrm{HCC}$} & S5 & 59.73 & 56.96 & 3.09 & 48.90 & 48.53 & 0.27 \\
\hline & S6 & 52.65 & & & 48.26 & & \\
\hline & S7 & 72.56 & & & 54.85 & & \\
\hline \multirow[t]{2}{*}{ FRC } & S8 & 64.56 & 69.12 & 3.36 & 54.49 & 54.37 & 0.45 \\
\hline & S9 & 70.23 & & & 53.77 & & \\
\hline
\end{tabular}


thank to the fibre inclusion in HCC slabs, which bridged the cracks and maintained the integrity of slabs avoiding a sudden failure.

2. The accumulated energy absorption of $\mathrm{HCC}$ slabs was 2.6 times higher than that of PC slabs and only $41 \%$ lower than that of FRC slabs, taking into account that the total fibre used in $\mathrm{HCC}$ slabs was only a half of that of the FRC ones.

3. The global dynamic response of PC, HCC and FRC slabs was quite similar and characterised by the formation of flexural cracks originating from the centre towards the corners and edges of the slab. However, the frustum cone-shaped plug was pushed off from HCC slabs at failure stage due to the punching shear local response. The fibre type and content used in FRC layer of HCC slabs was quite relevant which resulted in transient behaviour from PC layer to FRC layer without any sign of delamination between them.

4. The empirical Hughes formulae, which employ tensile strength of material for design structure against impact, were used to evaluate the slabs PC, HCC and FRC under impact as same as experimental condition. Empirical results were somewhat in agreement with experimental results in this study. However, since they are nothing but mathematical formulae, they could not have included so far the full role of fibres such as toughness enhancement and crack control in their formulae.

5. Based on an extended yield line theory, analytical analysis of slabs under static load in failure regime and the obtained dynamic test results have showed that their correlation of dynamic and static load of PC, FRC and HCC material was in the similar order of magnitude as prescribed in design code for concrete structures against impact.

\section{ACKNOWLEDGEMENTS}

The work presented here was partially funded by the EU-6FP-011817-2 TUNCONSTRUCT project and the JAE program of CSIC, which are gratefully acknowledged. The authors also would like to express their gratitude for valuable comments of reviewers.

\section{REFERENCES}

1. Bangash, M.Y.H. (1993) Impact and Explosion: Analysis and Design, p. 856, Blackwell Scientific Publications, London.

2. Bentur, A.; Mindess, S. (2007) Fiber reinforced cementitious composites, p. 625, Second edition, Taylor \& Francis, London and New York.

3. Brandt, A.M. (2007) Fibre reinforced cement-based (FRC) composites after over 40 years of development in building and civil engineering. Composite Structures, 86 [1-3], 3-9. http://dx.doi.org/10.1016/j.compstruct.2008.03.006.

4. Cánovas, M.F.; Hernando, V.M. (2012) Behavior of steel fiber high strength concrete under impact of projectiles. Mater.
Construcc. 62 [307], 381-396. http://dx.doi.org/10.3989/ mc.2012.00911.

5. Melian, G.; Barluenga, G.; Hernandez-Olivares, F. (2010) Toughness increase of self-compacting concrete reinforced with polypropylene short fibers. Mater. Construcc., 60 [300], 83-97. http://dx.doi.org/10.3989/mc.2010.52309.

6. Puertas, F.; Gil-Maroto, A.; Palacios, M.; Amat, T. (2006) Alkali-activated slag mortars reinforced with AR glassfibre. Performance and properties. Mater. Construcc. 56 [283] (2006), pp. 79-90. http://dx.doi.org/10.3989/mc.2006. v56.i283.

7. Daudeville, L.; Malecot, Y. (2011) Concrete structures under impact. European Journal of Environmental and Civil Engineering. 15 [1], 101-140. http://dx.doi.org/10.1080/ 19648189.2011.9695306

8. Li, Q.H.; Xu, S.L. (2009) Experimental investigation and analysis on flexural performance of functionally graded composite beam crack-controlled by ultrahigh toughness cementitious composites. Science in China Series E: Technological Sciences. 52 [6], 1648-1664. http://dx.doi.org/ 10.1007/s11431-009-0161-x.

9. Caratelli, A.; Meda, A.; Rinaldi, Z.; Romualdi, P. (2011) Structural behaviour of precast tunnel segments in fiber reinforced concrete. Tunnelling and Underground Space Technology, 26 [2], 284-291. http://dx.doi.org/10.1016/j. tust.2010.10.003.

10. Shen, B.; Hubler, M.; Paulino, G.H.; Struble. L. (2008) Functionally-graded fiber-reinforced cement composite: Processing, microstructure, and properties. Cem. \& Concr. Comp., 30 [8], 663-673. http://dx.doi.org/10.1016/j. cemconcomp.2008.02.002.

11. Río, O.; Nguyen, V.D.; Turrillas, X.: "Functionally-graded self-compacting cement composites". In: Proceedings of Fifth North American Conference on the Design and Use of Self-Consolidating Concrete. Chicago-USA; 2013, p. 10 (CD).

12. Nguyen, V.D.; Río, O.; Sánchez-Gálvez, V.: "Hybrid cementbased composite elements" In: Proceeding of 9th Symposium on High Performance Concrete: Design, Verification \& Utilization. Rotorua-New Zealand; 2011, p. 6 (CD).

13. Nes, G.L.; Arve, O.J. (2008) Hybrid concrete structure Experimental and numerical investigation of beams with lightweight concrete and fibre-reinforcement. Journal of Nordic Concrete Research, 38 [2], 1-20.

14. Roesler, J.; Paulino, G.; Gaedicke, C.; Bordelon, A.; Park, K. (2007) Fracture Behavior of Functionally Graded Concrete Materials for Rigid Pavements. Transportation Research Record, 2037 [1], 40-49. http://dx.doi.org/10.3141/ 2037-04.

15. Chung, Y.L.; Chen, W.T. (2007) Bending behavior of FGM-coated and FGM-undercoated plates with two simply supported opposite edges and two free edges. Composite Structures, 81 [2], 157-167. http://dx.doi.org/10.1016/j. compstruct.2006.08.006

16. Cannillo, V.; Lusvarghi, L.; Manfredini, T.; Montorsi, M.; Siligardi, C.; Sola, A. (2007) Glass-ceramic functionally graded materials produced with different methods. J. European Ceramic Society, 27 [2-3], 1293-1298. http:// dx.doi.org/10.1016/j.jeurceramsoc.2006.05.033.

17. Saatci, S.; Vecchio, F.L. (2006) Effects of shear mechanisms on impact behaviour of reinforced concrete beams. $A C I$ Structural Journal, 106 [1], 78-86.

18. Alvarez, A.P.; Ros P.S. editores. (2012) Hormigón Autocompactante: avance y oportunidades, p. 530, Procc. $3^{\circ}$ Congreso Iberoamericano sobre Hormigón Autocompactante, Madrid.

19. Comisión Permanente del Hormigón: Instrucción de Hormigón Estructural. (2008) EHE-08, Ministerio de Fomento, Madrid.

20. Ferrara, L.; Tregger N.; Shah, S.P. (2010) Flow-Induced Fiber Orientation in SCSFRC: Monitoring and Prediction. In: Khayat K.H. and Feys D. editors. Proceedings of the international RILEM workshop "Design, Production and Placement of Self-Consolidating Concrete-SCC2010", Montreal-Canada, 417-428. 
21. Enfedaque, A.D. (2008) Resistencia a impacto de morteros de cemento reforzados con fibra de vidrio (GRC), p. 292, $\mathrm{PhD}$ thesis, Universidad Politécnica de Madrid.

22. Mindess, S.; Bentur, A. (1985) A preliminary study of the fracture of concrete beams under impact loading, using high speed photography. Cem. Concr. Res., 15 [3], 474- 484. http://dx.doi.org/10.1016/0008-8846(85)90121-8.

23. Sánchez-Gálvez V. (2012) Materiales para la Defensa, p. 109, Primera edición, Fundación Rogelio Segovia para el desarrollo de las Telecomunicaciones, Madrid.

24. Suaris, W.; Shah, S. P. (1983) Properties of concrete subjected to impact. Journal of Structural Engineering, 109 [7], 1727-1741. http://dx.doi.org/10.1061/(ASCE)0733-9445 (1983)109:7(1727).

25. Ong, K.C.G.; Basheerkhan, M.; Paramasivam, P. (1999) Resistance of fibre concrete slabs to low velocity projectile impact. Cem. Concr. Comp., 21 [5-6], 391-401. http:// dx.doi.org/10.1016/S0958-9465(99)00024-4.

26. Nataraja, M.C.; Dhang, N.; Gupta, A.P. (1999) Statistical variations in impact resistance of steel fiber subjected to drop-weight test. Cem.Concr. Res., 29 [7], 989-95. http:// dx.doi.org/10.1016/S0008-8846(99)00052-6.

27. Rahmani, T.; Kiani, B.; Shekarchi, M.; Safari, A. (2012) Statistical and experimental analysis on the behavior of fiber reinforced concretes subjected to drop-weight test. Constr. Build Mater, 37 [12], 360-369. http://dx.doi.org/10.1016/j. conbuildmat.2012.07.068.

28. Yankelevsky, D.Z. (1997) Local response of concrete slabs to low velocity missile impact. Int. J. Impact Engng., 19 [4], 331-343.

29. Mougina J.P.; Perrotina P.; Mommessina, M.; Tonnelob, J.; Agbossoua, A. (2005) Rock fall impact on reinforced concrete slab: an experimental approach. Int. J. Impact Engng, 31 [2], 169-183. http://dx.doi.org/10.1016/j.ijimpeng.2003.11.005.
30. Zhang, J.; Maalej, M.; Quek, S.T. (2007) Performance of hybrid-fiber ECC blast/shelter panels subjected to dropweight impact. ASCE, J. Mater. Civ. Eng., 19 [10], 855-863. http://dx.doi.org/10.1061/(ASCE)0899-1561(2007)19:10 (855).

31. Sudarsana Rao, H.; Ghorpade, V.G.; Ramana, N.V.; Gnaneswar, K. (2010) Response of SIFCON two-way slabs under impact loading. Int. J. Impact Engng., 37 [8], 928941. http://dx.doi.org/10.1016/j.ijimpeng.2009.06.003.

32. Zaera, R.; Sanchez-Galvez, V. (1998) Analytical modelling of normal and oblique ballistic impact on ceramic/ metal lightweight armours. Int. J. Impact Eng., 21 [3], 133-148. http://dx.doi.org/10.1016/S0734-743X(97)00035-3.

33. Chocron Benloulo, I.S.; Sánchez-Gálvez, V. (1998) A new analytical model to simulate impact onto ceramic/composite armors. Int. J. Impact Engng., 21 [6], 461-471 http:// dx.doi.org/10.1016/S0734-743X(98)00006-2.

34. Garg, A.C. (1988) Delamination-a damage mode in composite structures. Engineering Fracture Mechanics, 29 [5], 557-584. http://dx.doi.org/10.1016/0013-7944(88)90181-6.

35. Bangash M.Y.H.; Bangash T. (2006) Explosion-Resistant Buildings. Design, Analysis and Case studies, p. 784, Springer, London.

36. Li, Q.M.; Reida, S.R.; Wen, H.M.; Telford A.R. (2005) Local impact effects of hard missiles on concrete targets. Int. J. Impact Engng., 32 [1-4], 224-284. http://dx.doi.org/ 10.1016/j.ijimpeng.2005.04.005.

37. Mosley, B.; Bungey, J; Hulse, R. (2007) Reinforced concrete design to Eurocode 2, p. $4206^{\text {th }}$ edition, Palgrave MC, New York.

38. CEB-FIP (1993) CEB-FIP Mode Code for Concrete structures under impact and impulsive loading", Comité EuroInternational du Béton, Bulletin d'Information, n87, Lausanne, Switzerland. 